
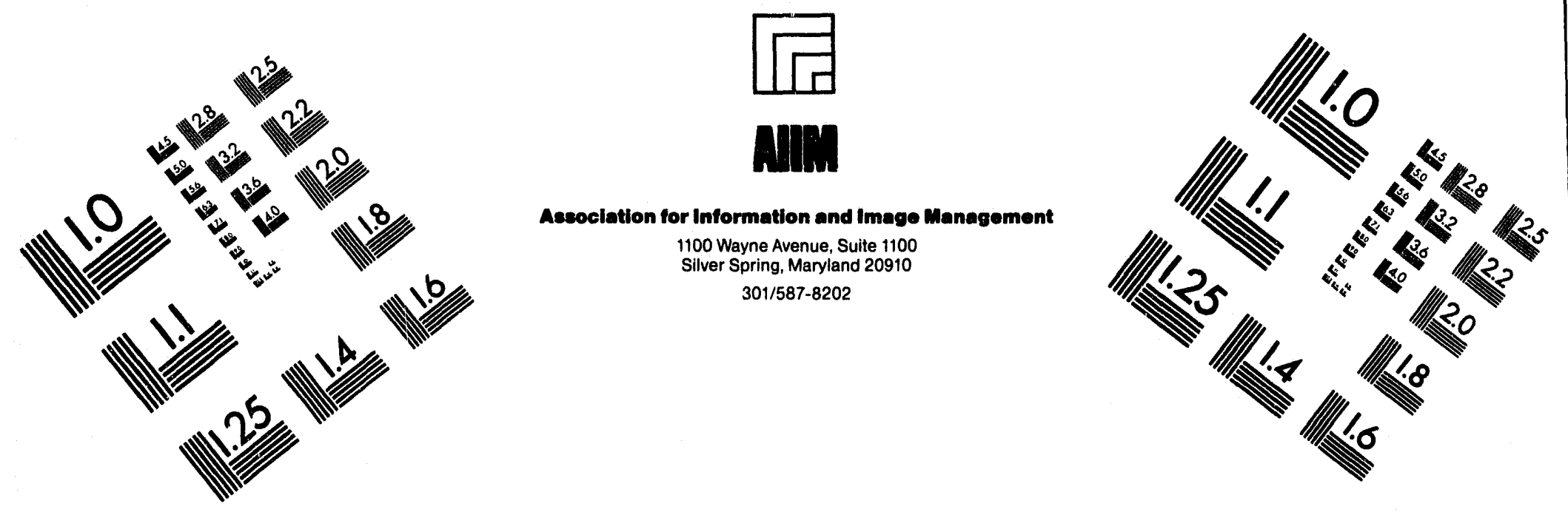

Centimeter

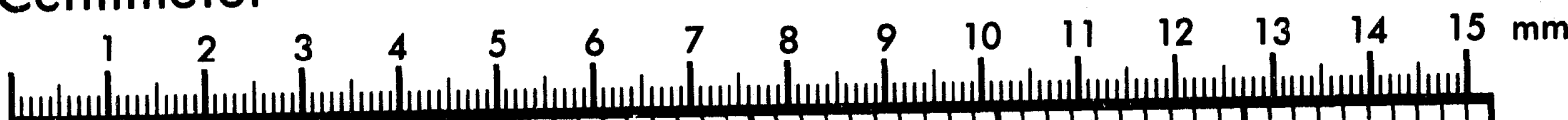

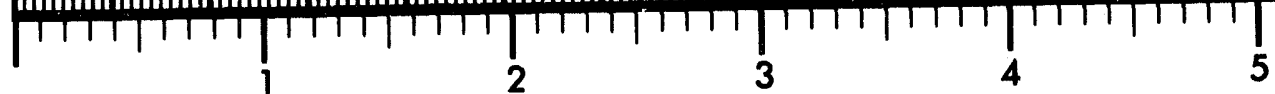
Inches
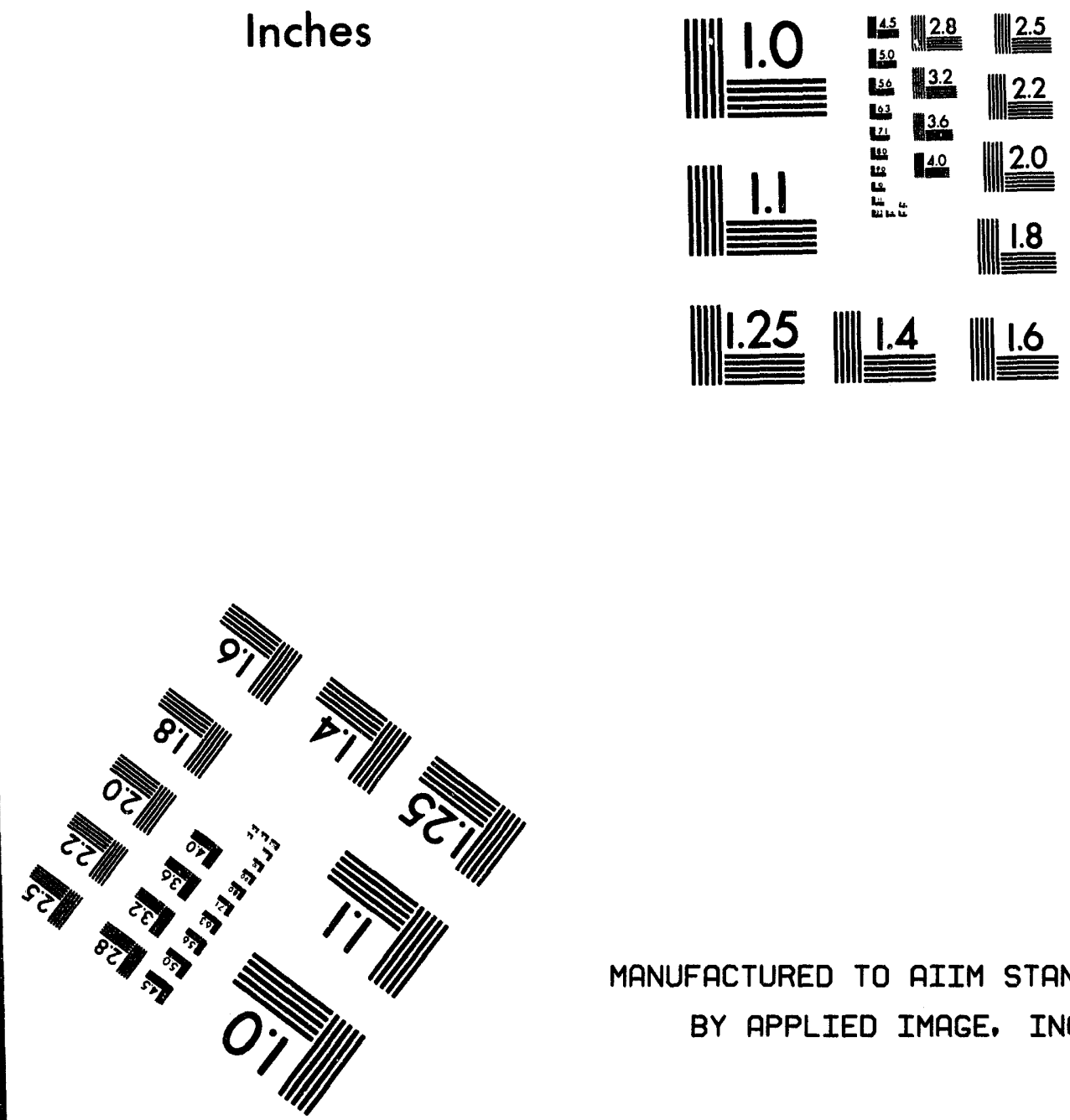

MANUFACTURED TO AIIM STANDARDS

BY APPLIED IMAGE, INC.

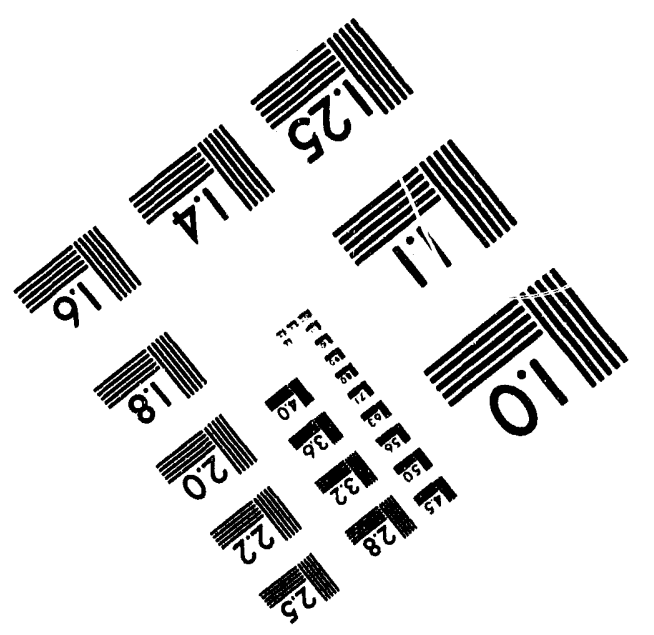



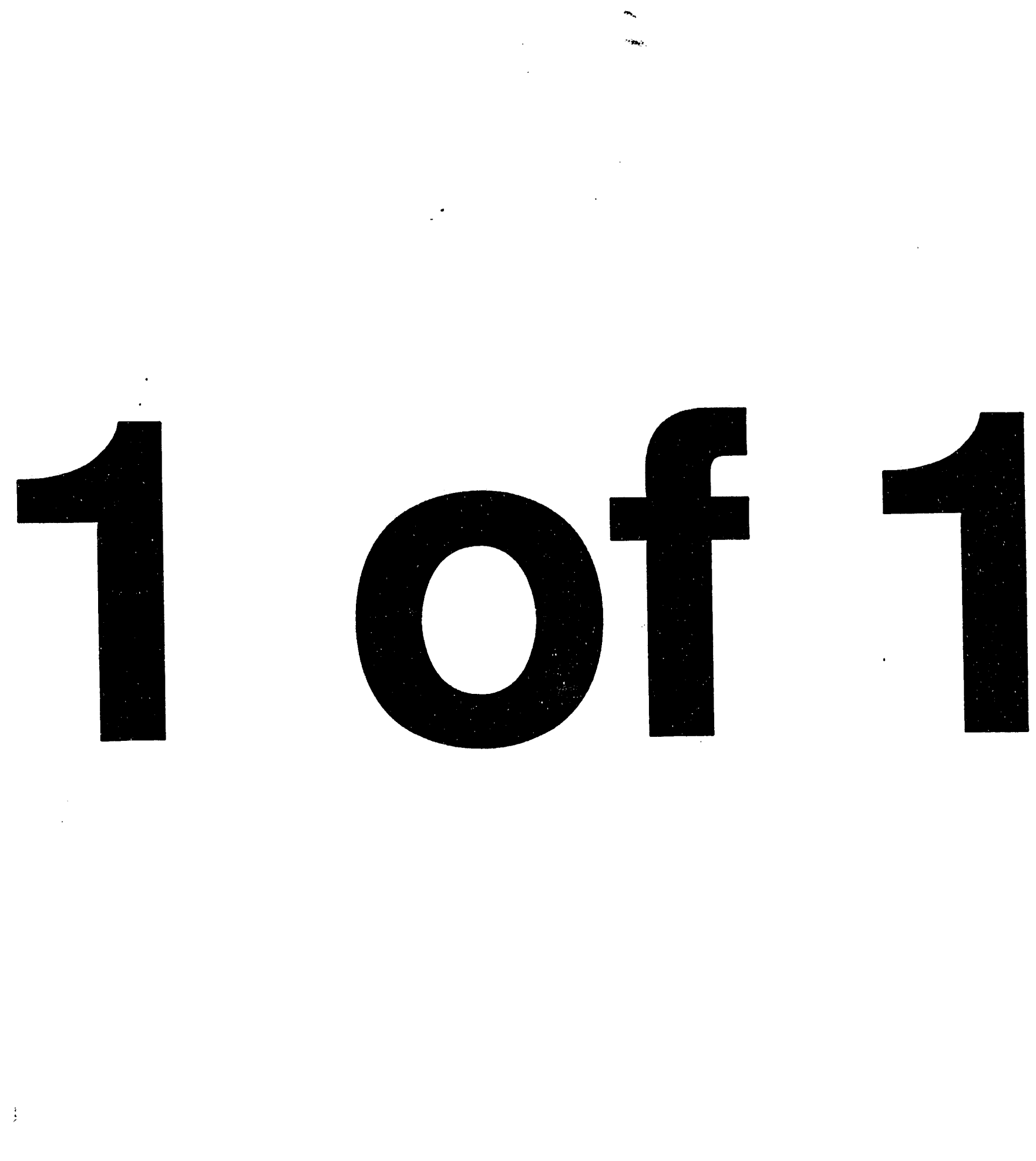


$$
\text { DOE/MT/9200/--6 }
$$

\title{
"ENVIRONMENTAL AND ECONOMIC ASSESSMENT OF DISCHARGES FROM GULF OF MEXICO REGION OIL AND GAS OPERATIONS"
}

Contract Number: DE-AC22-92MT92001

Continental Shelf Associates, Inc.

759 Parkway Street

Jupiter, Florida 33477

(407) $746-7946$

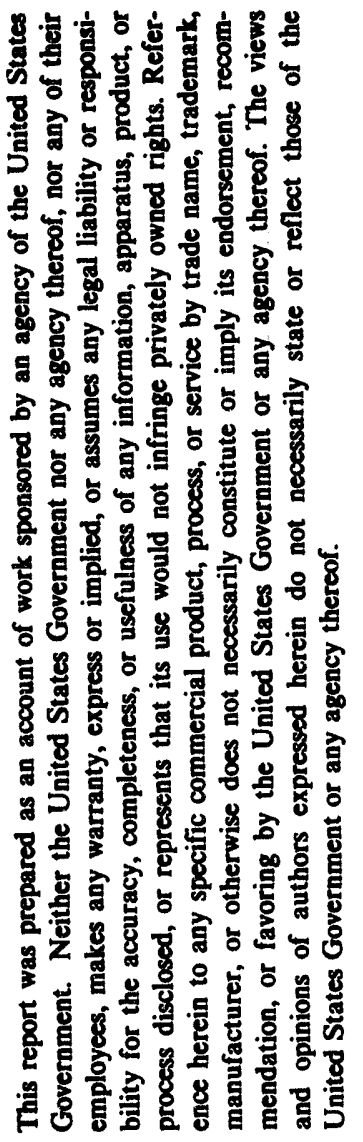

\author{
28 January 1994 \\ Contract Date: 23 June 1992 \\ Anticip: ited Completion Date: 22 June 1995 \\ Government Award for Current Year: $\$ 3,709,143$
}

Program Manager and Principal Investigator:

David A. Gettleson, Ph.D.

Continental Shelf Associates, Inc.

Technical Project Officer (COR):

Brent W. Smith, D.P.A.

U.S. Department of Energy

Metairie Site Office

900 Commerce Road, East

New Orleans, Louisiana 70123

(504) $734-4970$

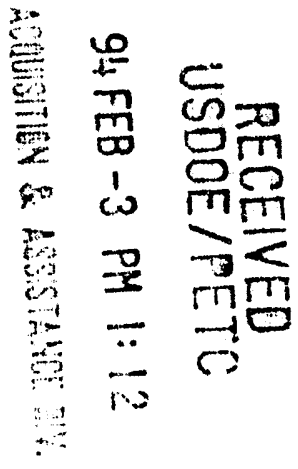

Quarterly Technical Progress Report

Reporting Period: 1 October to 31 December 1993

US/DOE Patent Clearance is not required prior to publication of this document.

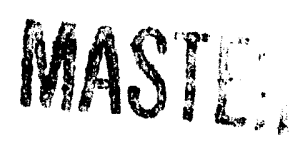

onsmisution of rHIS Documerit is UMLIMITED 


\section{TABLE OF CONTENTS}

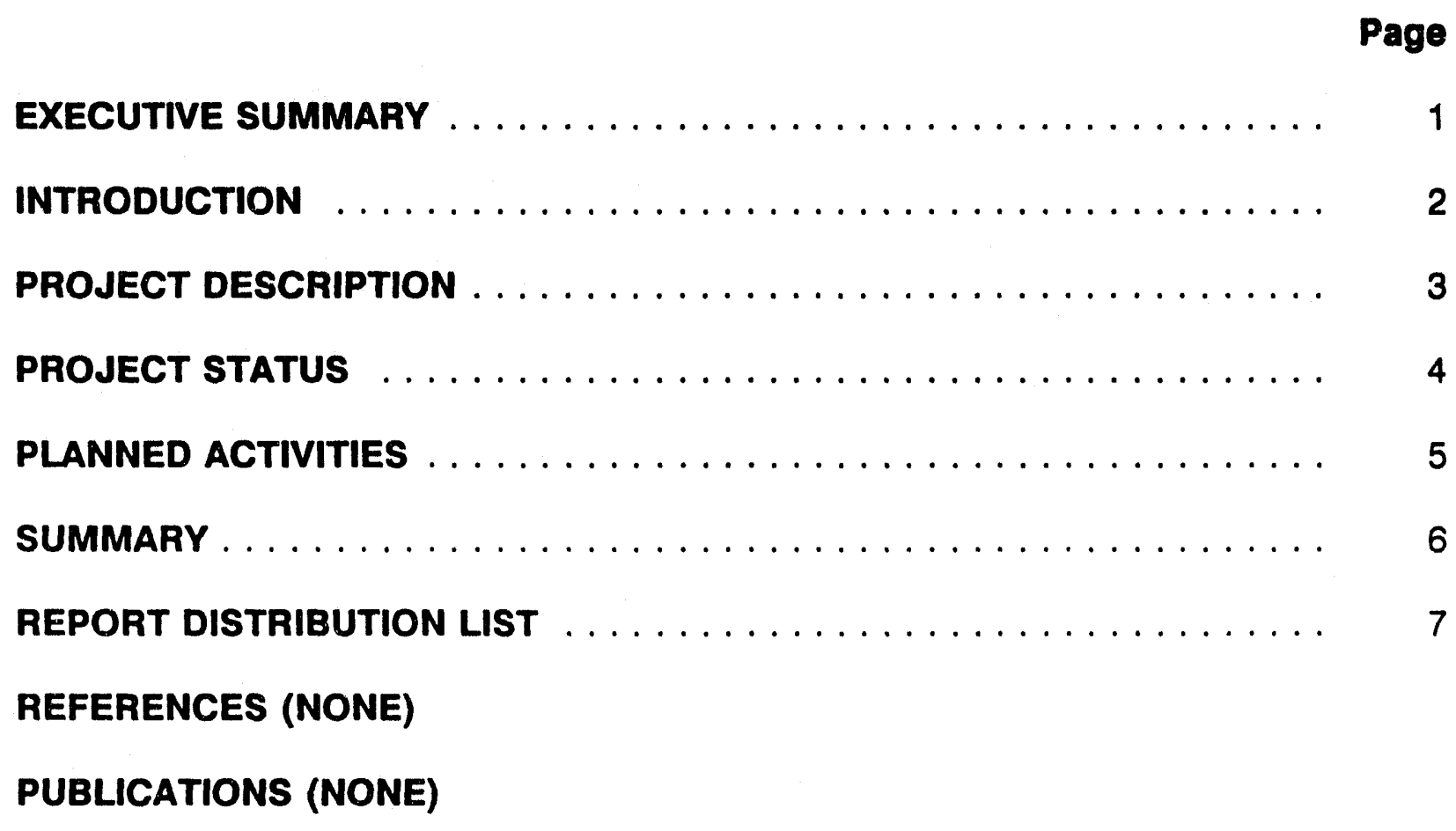




\section{EXECUTIVE SUMMARY}

Task 2 (Preparation of the Sampling and Analysis Plan) activities involved the incorporation of the offshore site selection process into the Sampling and Analysis Plan. Task 3 (Environmental Field Sampling and Analysis of NORM, Heavy Metals, and Organics) work included making decisions on tissue analyses and performing analyses of water and sediment samples. Task 4 (Monitoring of the Recovery of Impacted Wetland and Open Bay Produced Water Discharge Sites in Coastal Louisiana and Texas) activities involved the completion of the spring benthos samples collection on pre-termination samples at Four Isle Dome and the first post-termination samples at Delacroix Island. Task 5 (Assessment of Economic Impacts of Offshore and Coastal Discharge Requirements on Present and Future Operations in the Gulf of Mexico Region) activities included continued work on development of a base case production forecast, modeling future production, and determining economic impact of treatment technologies. Task 6 (Synthesis of Gulf of Mexico Seafood Consumption and Use Patterns) work involved the completion of the fall survey season and the initiation of the survey data assembly. Task 7 (Technology Transfer Plan) activities included presentations at the Society of Environmental Toxicology and Chemistry annual meeting and Minerals Management Service Information Transfer Meeting. Task 8 (Project Management and Deliverables) activities involved the submission of the necessary reports and routine management. 


\section{INTRODUCTION}

This report represents the sixth quarterly technical summary for the study "Environmental and Economic Assessment of Discharges from Gulf of Mexico Region Oil and Gas Operations." Activities associated with Tasks 2 through 8 are discussed in this report. 


\section{PROJECT DESCRIPTION}

Continental Shelf Associates, Inc. (CSA) was contracted to conduct a threeyear study of the environmental and health related impacts of produced water and sand discharges from oil and gas operations. Data on naturally occurring radioactive materials (NORM), heavy metals, and hydrocarbons in water, sediment, and biota will be collected and evaluated. Health related impacts will be studied through field collections and analyses of commercially- and recreationally-important fish and shellfish tissues. Additionally, information on seafood catch, consumption, and use patterns for the Gulf of Mexico will be gathered and analyzed. The facilities to be studied will include both offshore and coastal facilities in the Gulf of Mexico. Coastal sites will be additionally studied to determine ecological recovery of impacted wetland and open bay areas. The economic impact of existing and proposed effluent federal and state regulations will also be evaluated.

The primary objectives of the project are to increase the base of scientific knowledge concerning (1) the fate and enyironmental effects of organics, trace metals, and NORM in water, sediment, and biota near several offshore oil and gas facilities; (2) the characteristics of produced water and produced sand discharges as they pertain to organics, trace metals, and NORM variably found in association with the discharges; (3) the recovery of four terminated produced water discharge sites located in wetland and high-energy open bay sites of coastal Louisiana and Texas; (4) the economic and energy supply impacts of existing and anticipated federal and state offshore and coastal discharge regulations; and (5) the catch, consumption and human use patterns of seafood species collected from coastal and offshore waters. The products of the effort will be a series of technical reports detailing the study procedures, results, and conclusions which contribute to the transfer of technology to the scientific community, petroleum industry, and state and federal agencies. 


\section{PROJECT STATUS}

Task 2 activities involved the incorporation of the offshore site selection process into the Sampling and Analysis Plan.

Task 3 activities included the preparation of analysis instructions on a sample by sample basis. Telephone discussions were held with Anne Meinhold, Brent Smith, and select Scientific Review Committee members regarding the analysis of tissue samples for radionuclides, hydrocarbons, and trace metals (see Attachment 1). Water and sediment samples are being analyzed and tissue samples are being prepared for analysis. The coordination of the collection of the produced water samples on a monthly basis from four platforms was continued. In addition, a produced sand washing project was conducted in conjunction with Shell Offshore, Denver Equipment, and Mr. Tom Randolph (see Attachment 2). A second produced sand washing project was also planned to be conducted in January of 1994 with Phillips Petroleum and Petrochemical Services, Inc. and Mr. Tom Randolph.

Task 4 activities included the completion of the spring benthos samples. The pre-termination samples were collected at Four Isle Dome. All sampling associated with the discharge was completed and the samples transferred to the laboratories for analysis. No marsh sampling was conducted due to a lack of suitable marsh habitat near the discharge. Dredge spoil from the canal lined both banks isolating the marsh. The first-post-termination sampling at Delacroix Island was also performed. All samples were transferred to the laboratories.

Task 5 activities involved development of a base case production forecast of oil, gas, and water production; compilation of the platform database information from the Minerals Management Service (MMS); development of operating cost algorithms for future production and undiscovered reserve analysis; compilation of the treatment technology data; and development of the regulatory scenarios.

Task 6 activities included continued interviews. The fall surveys were completed and the survey data assembly was initiated in December. Responses were received from the mailout survey to Texas restaurants.

Task 7 activities included presentations at the Society of Environmental Toxicology and Chemistry annual meeting in Houston, Texas and at the MMS Information Transfer Meeting in New Orleans, Louisiana.

Task 8 activities included the submission of the necessary reports and routine management. 


\section{PLANNED ACTIVITIES}

Tasks 1 and 2 activities will include the completion of the Sampling and Analysis Plan. (The completion of this report has been delayed due to the concentration on preparing a proper inventory of Task 3 samples and determining which samples should be analyzed.) A meeting will be held in January between members of DOE, Brookhaven National Laboratory, CSA and selected subcontractors, and industry to discuss overall program objectives (see Attachment 3).

Task 3 activities will include the continued preparation (dissections) of tissue samples for analysis and preparation of analysis instructions. Laboratory analyses of the water and sediment samples will continue. The monthly collection of produced water samples will continue.

Task 4 activities will include continued laboratory analyses of samples and data management.

Task 5 activities will include the continued analysis of available production operations data to quantify current discharge volumes. Data will also continue to be gathered to model current operating practices and forecast costs and requirements associated with potential future discharge regulations. Treatment scenarios will be prepared to evaluate costs of the future regulations.

Task 6 data from the interviews of sport fishing groups, recreational and commercial fishermen, wholesalers/processors, and restaurants will be statistically analyzed for determination of potential trends. Additional responses to the mailout survey to restaurants are expected.

No Task 7 activities are anticipated.

Task 8 activities will involve the submission of all required reports. The revised management and cost plan will be submitted once the results of the Steimle \& Associates, Inc. audit are received by DOE and any relevant information to the cost plan is transmitted to CSA. 


\section{SUMMARY}

Task 2 activities involved the incorporation of the offshore site selection process into the Sampling and Analysis Plan. Task 3 work included making decisions on tissue analyses and performing analyses of water and sediment samples. Task 4 activities involved the compietion of the spring benthos samples collection on pre-termination samples at Four Isle Dome and the first post-termination samples at Delacroix Island. Task 5 activities included continued work on development of a base case production forecast, modeling future production, and determining economic impact of treatment technologies. Task 6 work involved the completion of the fall survey season and the initiation of the survey data assembly. Task 7 activities included presentations at the Society of Environmental Toxicology and Chemistry annual meeting and Minerals Management Service Information Transfer Meeting. Task 8 activities involved the submission of the necessary reports and routine management. 


\section{REPORT DISTRIBUTION LIST}

Document Control Center

Three (3) copies

U.S. Department of Energy

Pittsburgh Energy Technology Center

P.O. Box 10940, MS 921-118

Pittsburgh, PA 15236-0940 


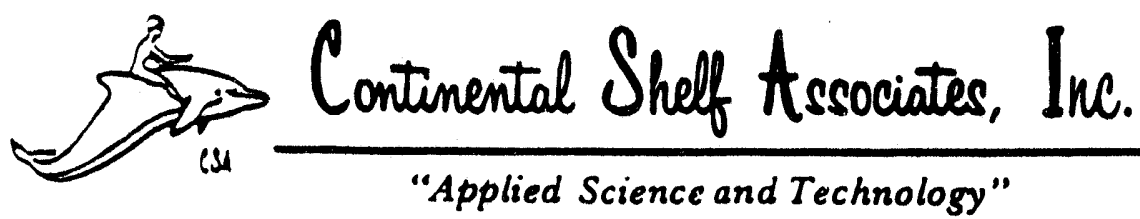

759 Parkway Street Jupiter, Florida $33477-9596$

Telephone: (407) 746-7946

Telefax: (407) 747-2954

\section{MEMORANDUM}

Date: $\quad 6$ December 1993

To: $\quad$ Brent Smith (U.S. Department of Energy)

Anne Meinhold (Brookhaven National Laboratory)

From: $\quad$ Al Hart

Subject: $\quad$ Analytical costs for tissue samples collected during the field sampling for offshore task of the project Environmental and Economic Assessment of Discharges from Gulf of Mexico Region Oil and Gas Operations

The conference call is scheduled for $1000 \mathrm{~h}$ on 7 December 1993. Please dial 800-857-4870 to enter the conference call. The password is "cough syrup."

The following table is provided for your review. We need to discuss the analytical strategy relative to the costs involved in analyzing the samples.

\begin{tabular}{||l|l|r|r|r|r|r|r||}
\hline \multirow{2}{*}{\multicolumn{2}{|c|}{ Analysis Strategy }} & \multicolumn{2}{c|}{ NORM } & \multicolumn{2}{c|}{ Hydrocarbons } & \multicolumn{2}{c|}{ Trace Metals } \\
\cline { 2 - 8 } & $\#$ & $\$$ & $\#$ & \multicolumn{1}{c|}{$\$$} & $\#$ & $s$ \\
\hline $\begin{array}{l}\text { CSA list of taxa } \\
\text { prior to } \\
\text { conference call }\end{array}$ & Whole/edible $^{1}$ & 267 & 152,559 & 106 & 62,402 & 87 & 30,630 \\
\cline { 2 - 8 } & Carcass $^{2}$ & 72 & 41,140 & 26 & 15,306 & 26 & 9,154 \\
\hline $\begin{array}{l}\text { Additional taxa } \\
\text { after conference } \\
\text { call }\end{array}$ & Whole/edible & 97 & 55,424 & -- & - & 6 & 2,112 \\
\cline { 2 - 8 } & Carcass & 37 & 21,141 & - & -- & 5 & 1,760 \\
\hline Measurement error & 27 & 15,427 & 27 & 15,895 & 24 & 8,450 \\
\hline Budget & 310 & 177,129 & 124 & 72,999 & 124 & 43,656 \\
\hline
\end{tabular}

${ }^{1}$ Analysis of whole specimen or edible tissue, depending on the taxon.

${ }^{2}$ Analysis of remainder of specimen after edible tissue has been removed. 


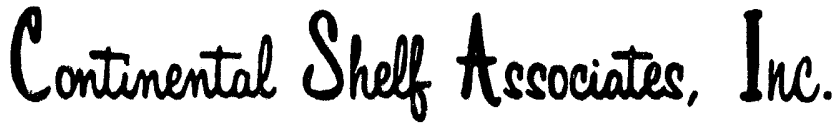 \\ "Applied Science and Technology"}

\section{MEMORANDUM}

Date: 10 December 1993

To: Brent Smith

From: Al Hart

Subject: Reduction in the number of tissue analyses for Task 3

It was decided during the 8 December 1993 conference call among Anne Meinhold, David Gettleson, you, and me that I would provide additional materials (see attached tables) to Anne Meinhold concerning the numbers of tissue analyses for Task 3 . She and I subsequently discussed the analysis strategy, and the purpose of this memo is to provide you with a summary of this discussion.

After reviewing the tables, Anne came to the conclusion that there were no specific sets of analyses that could be obviously eliminated. One possibility is to cut the analysis of the carcasses, but then the ability to perform the ecological risk assessment is reduced.

As you can see from the 6 December 1993 memo sent to you prior to the 8 December 1993 conference call, the estimated costs associated with analyzing all of the tissue samples are:

$\begin{array}{lr}\text { NORM } & \$ 285,691 \\ \text { Hydrocarbons } & 93,603 \\ \text { Trace Metals } & 52,106\end{array}$

for a total of $\$ 431,400$, which is $\$ 137,616$ over the budgeted funds $(\$ 293,784)$. Deleting the analyses of carcass would result in a total of $\$ 342,899$, which is $\$ 49,115$ over the budgeted funds. Other options include only analyzing carcasses for NORM, which would reduce the ability to perform the ecological risk assessment for hydrocarbons and trace metals.

Although you stated during the conference call that we should proceed pending the discussion between Anne and I, we felt that you should review this information and discuss it with her in light of DOE's objective. If necessary, I would be glad to discuss the options with you and/or provide you with additional information. Please advise me of your selected course of action, and I will prepare a memo stating CSA's understanding for your concurrence.

Thank you for your effort and cooperation.

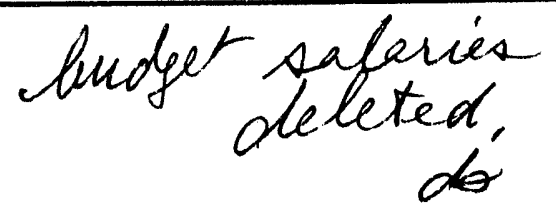




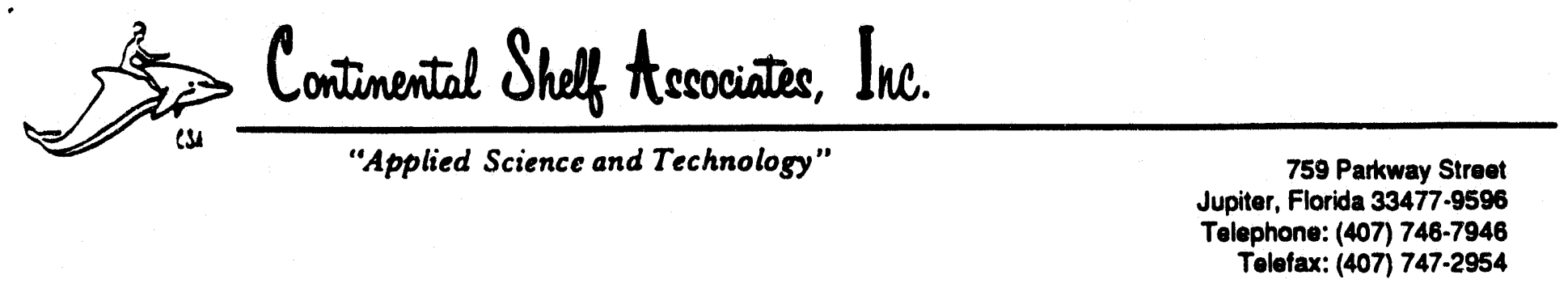

\section{MEMORANDUM}

To: Meeting Attendees (List Attached)

From: Drs. Brent Smith (DOE) and David Gettleson (CSA)

Date: 3 January 1994

Re: Requesting Attendance at Department of Energy Meeting on 18 January 1994

The purpose of this memo is to request your attendance at a meeting to be held at the Metairie, Louisiana Department of Energy (DOE) office (900 Commerce Road East, New Orleans, Louisiana 70123) on 18 January 1994 at 10:00 a.m. The meeting will be held to discuss the DOE study (Contract No. DE-AC22-92MT92001: "Environmental and Economic Assessment of Discharges from Gulf of Mexico Region Oil and Gas Operations") being conducted by Continental Shelf Associates, Inc. and their subcontractors. Due to increased costs above the budgeted amount for sampling and analysis plan development and sample collection and analyses (due to lowered NORM detection limits and quantity of samples), it is necessary to carefully re-examine the objectives of the study relative to produced water and sand discharges and both current and future regulations. Considerations need to include the importance of the following:

1. human health risk assessment (NORM) offshore;

2. ecological risk assessment (NORM, hydrocarbons, and trace metals) offshore;

3. human health risk assessment (NORM) coastal area;

4. ecological risk assessment (NORM, hydrocarbons, and trace metals) coastal area;

5. ecological recovery at one, two, or three coastal sites; and

6. additional produced sand data collection.

We would like to discuss your opinion on these tasks relative to the current and future regulation of produced water and produced sand discharges. 
Continental Sheif Asscelates, Inc.

Department of Energy Contract NO. DE-AC22-92MT92001

Proposed attendees for meeting

in New Orleans on Tuesday, 18 January 1994

Dr. David A. Gettleson

(407) 746-7946

Dr. Alan D. Hart

FAX (407) 747-2954

Continental Shelf Associates, Inc.

759 Parkway Street

Jupiter, Florida 33477

Dr. Brent W. Smith (COR)

Dr. Jerry Ham

U.S. Department of Energy

Metairie Site Office

900 Commerce Road East

New Orleans, Louisiana 70123

Dr. Maureen Mulino

(504) 831-2574

Steimle and Associates, Inc.

FAX: (504) 835-9410

3826 Airline Highway

Metairie, Louisiana 70001

Ms. Glenda Smith

(504) 734-4970

(504) 734-4906

FAX: (504) 734-4909

ICF Resources Incorporated

9300 Lee Highway

Fairfax, Virginia 22031-1207

Mr. Tom Randolph

(504) 767-6302

Randolph Consulting

FAX (504) 767-6226

P.O. Box 82860

Baton Rouge, Louisiana 70884

Ms. Anne Meinhold

Brookhaven National Laboratory

Upton, Long Island, New York 11973

(703) 934-3853

FAX: (703) 691-3349

Mr. Dave LeBlanc

Texas Mid-Continent Oil and Gas Association

c/o Texaco Exploration and Production Inc.

400 Poydras Street

New Orleans, Louisiana 70130

FAX (504) 593-4081

(516) 282-2004

FAX (516) 282-7867

(504) 595-1464 
Page 2 of 2

Dr. James Ray

Offshore Operators Committee

Environmental Science Task Force

Shell Oil Company

900 Louisiana Street, Room 1301

Houston, Texas 77002

Mr. Don Briggs

Louisiana Independent Oil and Gas Association

P.O. Box 4069

Baton Rouge, Louisiana 70821

Mr. Mike Lyons

Vice-President

Louisiana Mid-Continent Oil and Gas Association

801 North Boulevard, Suite 201

Baton Rouge, Louisiana 70802-5727

Ms. Nancy Johnson

U.S. Department of Energy, Office of Fossil Energy 1000 Independence Avenue, S.W.

Washington, DC 20585
(713) $241-3060$

FAX (713) 241-0256

(800) 443-1433

(318) 232-6520

(504) 387-3205

FAX (504) 344-5502

(202) 586-6458

FAX (202) 586-6221 

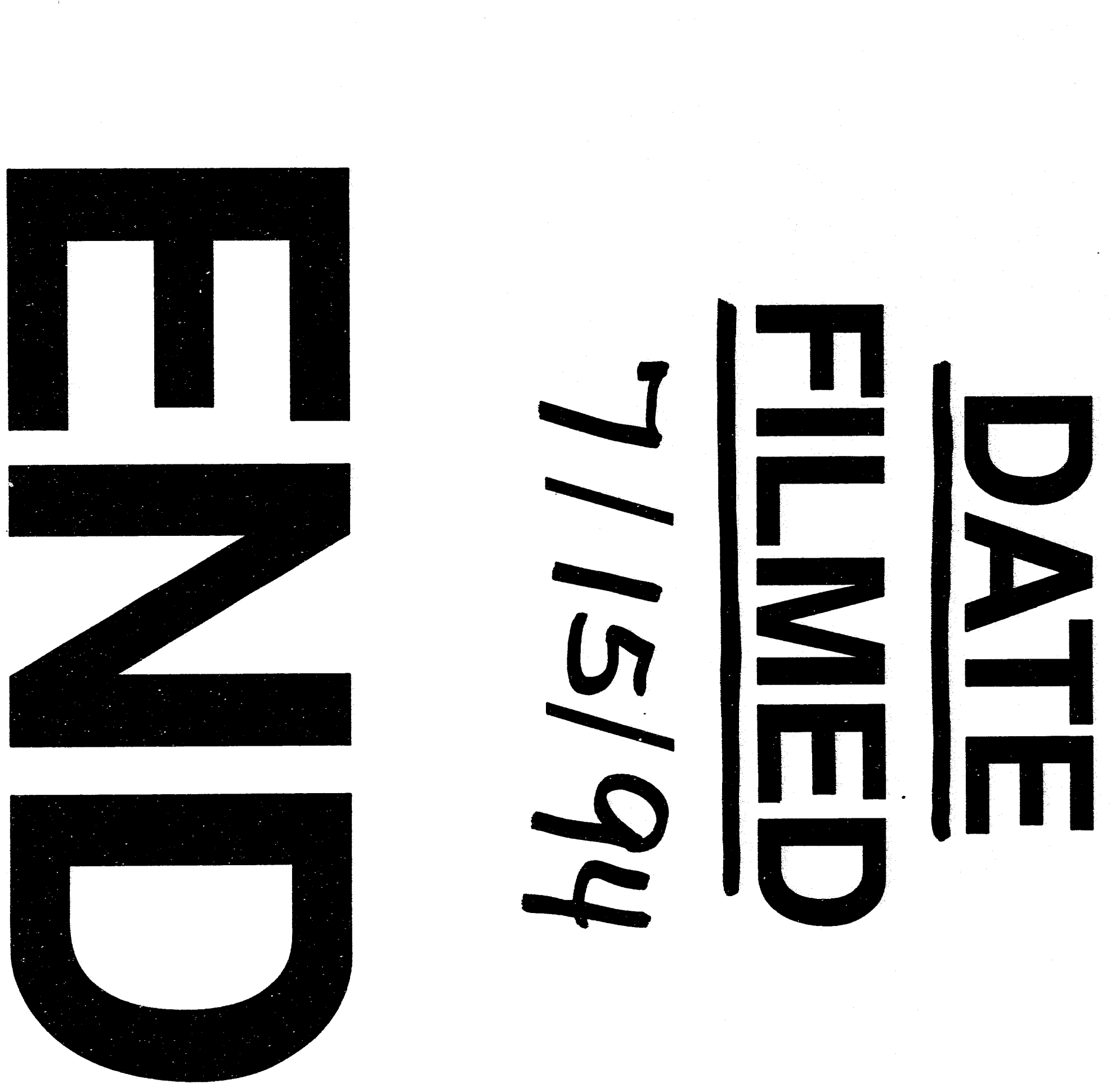
$$
-
$$ 